\title{
SWOT Analysis of Cross-border E-commerce Development in China under the Background of Internet Plus
}

\author{
Jingjing Xie \\ School of Economics \& Management, Nanjing University of Science \& Technology, China \\ xjj1991@126.com
}

\begin{abstract}
With the development of the information technology and economic globalization, cross-border e-commerce has become a new growth point of economic development of foreign trade. It is a new driving force to promote the upgrading of industrial structure. This paper analyzes the advantages, disadvantages, opportunities and challenges in the development of cross-border e-commerce. With the implementation of the "Internet Plus" and "The Belt and Road", China's cross-border e-commerce market is broad, but it has disadvantages in the logistics, payment, credit system and still faces the challenges of foreign enterprises. Based on this, this paper puts forward the related solutions and suggestions from the view of government, enterprises and universities to make cross-border e-commerce ecosystem more perfect.
\end{abstract}

Keywords: Cross-border E-commerce; Internet Plus; SWOT Analysis.

\section{Introduction}

On March 5, 2015, Premier Li Keqiang put forward the Internet Plus initiative for the first time in the government work report, to integrate mobile Internet, cloud computing, big data and the Internet of Things with modern manufacturing, to promote e-commerce, industrial Internet and Internet finance healthy development, and to guide international expansion by Internet companies [1]. Plus represents the traditional industries, Internet Plus, the new economic form, is conducted to enhance innovative productivity of the traditional economies with the use of Internet thinking, to create new areas of economic development in the new ecology with Internet infrastructure and tools [2]. In this context, cross-border e-commerce uses Internet plus foreign trade, combining the Internet with foreign trade, for deep integration. Cross-border e-commerce is an international business activity defined as, using e-commerce platform to achieve transactions, payment and settlement, and transporting merchandises by cross-border logistics to complete the transaction [3]. Cross-border e-commerce overturns the traditional form of foreign trade, improves the trade pattern, and promotes economic development, and also changes the world trade reform.

\section{The development of cross-border e-commerce in China}

Over the past few years, due to the impact of international and domestic factors, China's foreign trade showed a slow, even a negative growth. According to China's E-commerce Research Centre, China's total amount of import and export declined 7\% in 2015, compared with those in 2014, the trend continued in the first half of 2016. However, cross-border e-commerce increased rapidly in recent years, and the annual growth rate remained at $30.95 \%$ or more. China's e-commerce market data monitoring report shows that in the first half of 2016 China's cross-border trade volume reached 2.6 trillion Yuan, at an increase of 30\% [4]. The proportion of cross-border trade volume in total imports and exports increased from $7 \%$ in 2011 to $22 \%$ in 2015. In the downturn of China's foreign trade growth, the rapid development of cross-border e-commerce is conducive to promoting the transformation and upgrading of traditional foreign trade enterprises, and is the new force to promote the upgrading of industrial structure. 


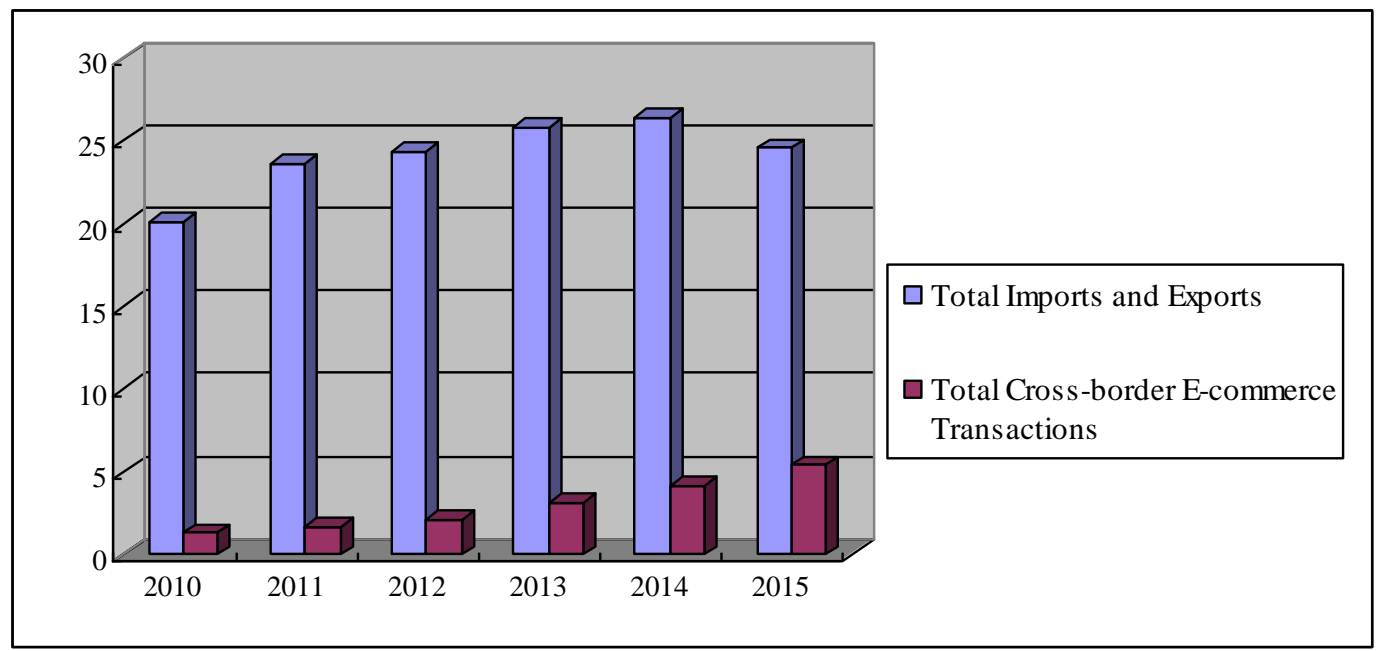

Figure 1.2010-2015 Total Imports and Exports and Cross-border E-commerce Transactions.

\section{SWOT analysis of cross-border e-commerce development in China}

\subsection{Strengths of Cross-border E-commerce Development}

3.1.1 Superior market base

Cross-border e-commerce is a combination of the Internet and international trade, which requires participants to use the network. According to CNNIC report, by the end of 2015, the scale of Chinese Internet users reached 688 million with 39.51 million added, online users up to 39.51 million. China's e-commerce market data monitoring report shows that in the first half of 2016, the size of China's online shopping users reached 480 million, all they may be potential traders of cross-border e-commerce suppliers. China's online retail market transactions reached 2.3 billion yuan at an increase of $43.4 \%$ in the first half of 2016 [4].

At the same time, the international market has a strong desire for Chinese goods. The rapid development of online market in Russia, Israel and other emerging countries provides a greater demand for cross-border e-commerce. Cross-border e-commerce orders are usually characterized by small batch, frequent number and small amount [5], which meets the demands of China's mass of small and medium enterprises, they can use e-commerce platform for rich marketing and provide adequate and quality goods.

\subsection{Weaknesses of Cross-border E-commerce Development}

\subsubsection{Payment issues}

The traditional payment model does not adapt to the needs of cross-border e-commerce, although the government encourages cross-border e-payment, but in a short period of time payment and settlement still need to be considered in cross-border e-commerce. The security and convenience of third-party payment platform are questionable, which is widely used, it's prone to false transactions, trading limits, slow return of funds and other issues.

\subsubsection{Logistics problems}

China's logistics system and infrastructure is still not perfect, especially related to cross-border logistics. At present, China's cross-border e-commerce logistics channels are mainly postal packages and international express delivery, with higher logistics costs and longer distribution cycle. In addition, the customs has strict requirements on the type and quantity of import and export goods, which increase both the cost and time of the transaction with a series of procedures and expenses.

\subsubsection{Lack of credit system}

Two sides of the cross-border e-commerce trade come from different countries, with different cultural backgrounds, living habits and communication styles, which are likely to lead to information asymmetry. Buyers can only understand the online merchandise through pictures and texts, but it is difficult to understand the quality of goods and after-sales service. Most foreign buyers pay by credit 
card, it is possible to reject the goods or withdraw the funds after receipt of the goods, which will cause the seller's losses. At present, there is no unified credit evaluation system and dispute resolution system.

\subsection{Opportunities of Cross-border E-commerce Development}

\subsection{1 "The Belt and Road" implementation}

With the implementation of "The Belt and Road", cross-border e-commerce has become a link, which will build a web silk road. Along the route area is mainly emerging economies and developing countries, which is one of the fastest-growing regions of the current global trade and cross-border investment, as the region's population is about 4.4 billion, economic aggregate is about $\$ 21$ trillion, accounting for about $63 \%$ and $29 \%$ of the world respectively [6]. In recent years, along The Belt and Road countries pay high attention to the construction of information and communication infrastructure, and have made positive progress in such aspects as network interconnection and informationization development. The implementation of "The Belt and Road" will benefit 65 countries and bring together multi-national, multi-ethnic and multi-cultural, which provides new markets and opportunities for cross-border e-commerce.

\subsubsection{Government policy support}

In recent years, the government attaches great importance to the development of cross-border e-commerce. In 2012, the Customs carried out cross-border e-commerce pilot project in Shanghai, Chongqing, Hangzhou, Ningbo and Zhengzhou, and expanded to other eight countries, including Guangzhou, Tianjin and so on. The establishment of e-commerce outsourcing service, public service platform and e-commerce park effectively improve the convenience of trade and optimize the cross-border financing environment, which are supported by the government policy. Government policy support promotes the development of cross-border e-commerce, but also provides a guarantee for enterprises taxes and operations.

\subsection{Threats of Cross-border E-commerce Development}

\subsubsection{Competition of foreign enterprises}

Cross-border e-commerce makes transactions more transparent, and reduces the problems of information asymmetry to some extent. For some industries, such as cosmetics, health products, in low credibility or have bigger price difference at home and abroad, domestic consumers may be more willing to purchase from international markets, so the domestic enterprises are facing survival challenges.

Domestic third-party payment platform, such as Alipay, although has a wider range of use in the country, but due to lower international profile and other reasons, the international market usage is far below the world's largest online payment company Paypal.

Foreign logistics companies are much more efficient than domestic companies, consumers may be more willing to choose foreign logistics companies.

\section{Measures}

\subsection{Optimize logistics system}

Logistics is the key to determining the survival of cross-border e-commerce. The key to the development of cross-border e-commerce logistics is to integrate foreign trade enterprise resources, to form the industrial chain, and to establish cross-border warehousing center. First of all, the government should improve the logistics system and infrastructure construction, in order to reduce the time and cost of logistics. The government should make plan and perfect the management system of customs clearance and quarantine, strengthen the construction of cross-border logistics infrastructure, and promote the development of intermodal business. For example, the opening of Yiwu-Xinjiang-Europe cargo train better meets the cross-border e-commerce logistics needs. Secondly, the construction of logistics parks should be strengthened, to achieve cross-border e-commerce logistics industry agglomeration effect, and to promote the formation of the logistics industry chain. In Hangzhou cross-border e-commerce industrial park enterprises can enjoy one-stop service, package clearance time reduces from one day to 2 hours. Last but not least, enterprises can establish overseas 
warehousing center, the goods would be shipped to the warehouse before shipment, which can shorten the logistics time and improve operational efficiency.

\subsection{Optimize payment system}

The government should improve laws and regulations, strengthen certification and supervision of the third-party payment and enhance the safety. Third-party payment agencies should strengthen the real-name registration of certified members to ensure the authenticity of the membership information. The government should strengthen the cooperation with other countries and seek the opportunity for third-party payment international cooperation. Third-party payment institutions should strengthen own development, such as regular evaluation to maintain security of user information and funds, and improve international reputation and recognition.

\subsection{Perfect credit system}

Big data provides new possibilities of credit evaluation for cross-border e-commerce. Mining, cleaning, matching, integrating various information through big data can convert it into effective credit data and provide the basis for the construction of the credit system [7]. The government should construct the credit evaluation system of cross-border e-commerce enterprises which includes the indexes of product quality and service quality, and establish the information registration platform for transaction subjects to ensure that the information is true and effective and to reduce information asymmetry.

\subsection{Strengthen Talents Cultivation}

Cross-border e-commerce has broader prospects, the demand for talents will be more urgent. People with marketing, publicity and other management capabilities, foreign language, law, computer and other professional skills, e-commerce knowledge and other talents are needed [8]. We should deepen the school-enterprise co-cultivation mode, strengthen the students' theoretical and practical ability with professional teachers, in order to meet the needs of cross-border e-commerce.

\section{Conclusions}

In the trend of Internet Plus, as a new form of foreign trade to promote the integration of global economy, cross-border e-commerce can stimulate the growth of foreign trade, optimize and adjust foreign trade structure, and improve the convenience of consumers. With the deepening of economic globalization and the integration of IT and economy, cross-border e-commerce ecosystem will be more perfect.

\section{References}

[1] Information on http://www.npc.gov.cn

[2] Yun Wang: Journal of Liaoning Institute of Science and Technology Vol. 18(2016), p. 53

[3] Fangfang Lin, Kangqi Peng, Shuangping Shen: Modern Business Trade Industry Vol. 27(2015), p. 37

[4] Information on http://www.100ec.cn

[5] Aiguo Tian: China Business and Market Vol. 30(2016), p. 99

[6] Zhizhong Liu: Modern Economic Research Vol. 12(2015), p. 40

[7] Jingyan Liu: Finance and Accounting Monthly Vol. 36(2016), p. 41

[8] Fan Li: Journal of Commercial Economics Vol. 20(2016), p. 57 